\title{
Vascular Cell Adhesion Molecule 1 Measurement
}

National Cancer Institute

\section{Source}

National Cancer Institute. Vascular Cell Adhesion Molecule 1 Measurement. NCI

Thesaurus. Code C82042.

The determination of the amount of vascular cell adhesion molecule 1 present in a sample. 